\title{
THE UPPER MANTLE TRANSITION REGION: ECLOGITE?
}

\author{
Don L. Anderson
}

Seismological Laboratory, California Institute of Technology, Pasadena, California 91125

\begin{abstract}
The upper.mantle transition region is usually considered to be peridotite which undergoes a series of phase changes involving spinel and post-spinel assemblages. There are difficulties associated with attempts to explain the 220,400 and $670 \mathrm{~km}$ discontinulties in terms of phase changes in a peridotitic mantle. Moreover, in a differentiated earth there should be large quantities of eclogite in the upper mantle. Eclogite is denser than $\mathrm{Al}_{2} \mathrm{O}_{3}$-poor mantle to depths of $670 \mathrm{~km}$, but it stays in the garnet stability field to pressures in excess of those required to transform depleted mantle to denser phases such as 11 menite and perovskite. Eclogite, therefore, remains above $670 \mathrm{~km}$. The selsmic properties of the transition region are more consistent with eclogite than peridotite. Most of the mantle's inventory of incompatible trace elements may be in this layer, which is a potential source region for some basalt magmas. The radioactivity in this layer is the main source of mantle heat flow, $0.7 \mu \mathrm{cal} / \mathrm{cm}^{2}$ sec, and drives upper mantle convection.
\end{abstract}

\section{Introduction}

There is abundant evidence that peridotite is important in the uppermost mantle. It is not clear that this situation can be generalized to the whole upper mantle. Depleted peridotite is less dense than any plausible parental material and it should concentrate immediately below the crust. There are several arguments that suggest that eclogite should be abundant somewhere in the upper mantle.

The earth is probably at least as well differentiated as the moon in which case it should have a basaltic crust more than $200 \mathrm{~km}$ in thickness. Estimates of the composition of the mantle [Ganapathy and Anders, 1974; Mason, 1966; Ringwood, 1975; Carter, 1970] are capable of yielding a basalt layer of the order of $400 \mathrm{~km}$ in thickness.

Whether the upper mantle is still enriched in a basaltic component depends on the relative densities of eclogite and $\mathrm{Al}_{2} \mathrm{O}_{3}$-poor mantle assemblages. This is controlled by the stability fields of garnet and such deep mantle phases as ilmenite and perovskite.

\section{Chemical Stratification of the Mantle}

There is now abundant evidence that even small bodies such as the moon can differentiate and produce basaltic magmas. It is likely that the earth was producing basaltic magmas while it was accreting. This would produce a chemically layered body with $\mathrm{Al}_{2} \mathrm{O}_{3}, \mathrm{CaO}, \mathrm{K}_{2} \mathrm{O}, \mathrm{Na}_{2} \mathrm{O}, \mathrm{U}, \mathrm{Th}, \mathrm{Ba}, \mathrm{Sr}$, etc. concentrated toward the outside. If estimates of mantle composition are anywhere near correct the earth could have produced the equivalent of more than $400 \mathrm{~km}$ of basalt. The current crust represents only a small fraction of this inventory. Subduction continuously returns basalt to the mantle but its ultimate fate has not been adequately addressed. Basalt inverts to eclogite at shallow depths and apparently sinks rapidly through the upper mantle. Basic questions are how deep does it sink and does it get reassimilated into the mantle?

The densities of the phases of basalt and $\mathrm{Al}_{2} \mathrm{O}_{3}$-poor silicates (primitive residual lower mantle) are shown in Figure 1 (from data of Liu [1977], Akaog1 and Akimoto [1977] and Ito and Matsui [1977]). The assemblages in the two systems are quite different. The $\mathrm{Al}_{2} \mathrm{O}_{3}-\mathrm{rich}$ assemblage provides the lightest (basalt) and heaviest (eclogite, garnetite) material at upper mantle $(<670 \mathrm{~km})$ pressures. Eclogite can sink to $600-700 \mathrm{~km}$ before it encounters assemblages in $\mathrm{Al}_{2} \mathrm{O}_{3}$-poor mantle which are denser. In the process of sinking it displaces residual lower mantle material upwards. The stratification of the mantle, whether achieved by early upper mantle-lower mantle separation or by subsequent subduction will therefore be basalt, peridotite, eclogite, garnetite overlying depleted, $\mathrm{Al}_{2} \mathrm{O}_{3}$-poor, lower mantle. This can give an average mantle composition identical to current estimates but the stratification is quite different.

The $220 \mathrm{~km}$ level is an important seismic [Lehmann, 1967; Hales et al., 1976] and tectonic discontinuity in the upper mantle [Anderson, 1979]. It is a good reflector of seismic energy which suggests that it is a compositional boundary. There is another sharp seismic discontinuity near $670 \mathrm{~km}$ [Anderson, 1967; Burdick and Helmberger, 1979; King and Calcagnile, 1976]. This appears to be $a$ chemical as well as a phase boundary [Anderson, 1977; Gaffney and Anderson, 1973; Burdick and Anderson, 1975; Butler and Anderson, 1978]. We will refer to the region between 220 and $670 \mathrm{~km}$ as the transition region.

Figure 2 is a bulk modulus-denstty plot of various minerals and mineral assemblages. The triangles are extrapolated zero-pressure values for different depth intervals of the mantle. Region I $(200+\mathrm{km})$ is consistent with either peridotite (olivine + opx + garnet) or eclogite (garnet $+c p x)$. In a peridotite mantle region II would be $\beta$-spinel + pyroxene \pm garnet s.s. \pm stishovite while in an eclogite mantle it would be garnet s.s. Both possibilities are consistent with the data. Below $500 \mathrm{~km}$ a peridotite mantle transforms to $\gamma$-spinel + garnet s.s. \pm stishovite while an eclogite mantle remains garnet $\mathrm{s.s}$. The bulk modulus is therefore consistent with either peridotite or eclogite between $\sim 200$ and $670 \mathrm{~km}$. Although this is a weak conclusion, it is significant that eclogite cannot be ruled out.

Estimates of the seismic velocities of various regions of the mantle extrapolated to surface conditions are given in Table 1 along with measurements on various rocks and minerals. The compressional velocity cannot distinguish between pyrolite and a gamet-rich eclogite. The shear 


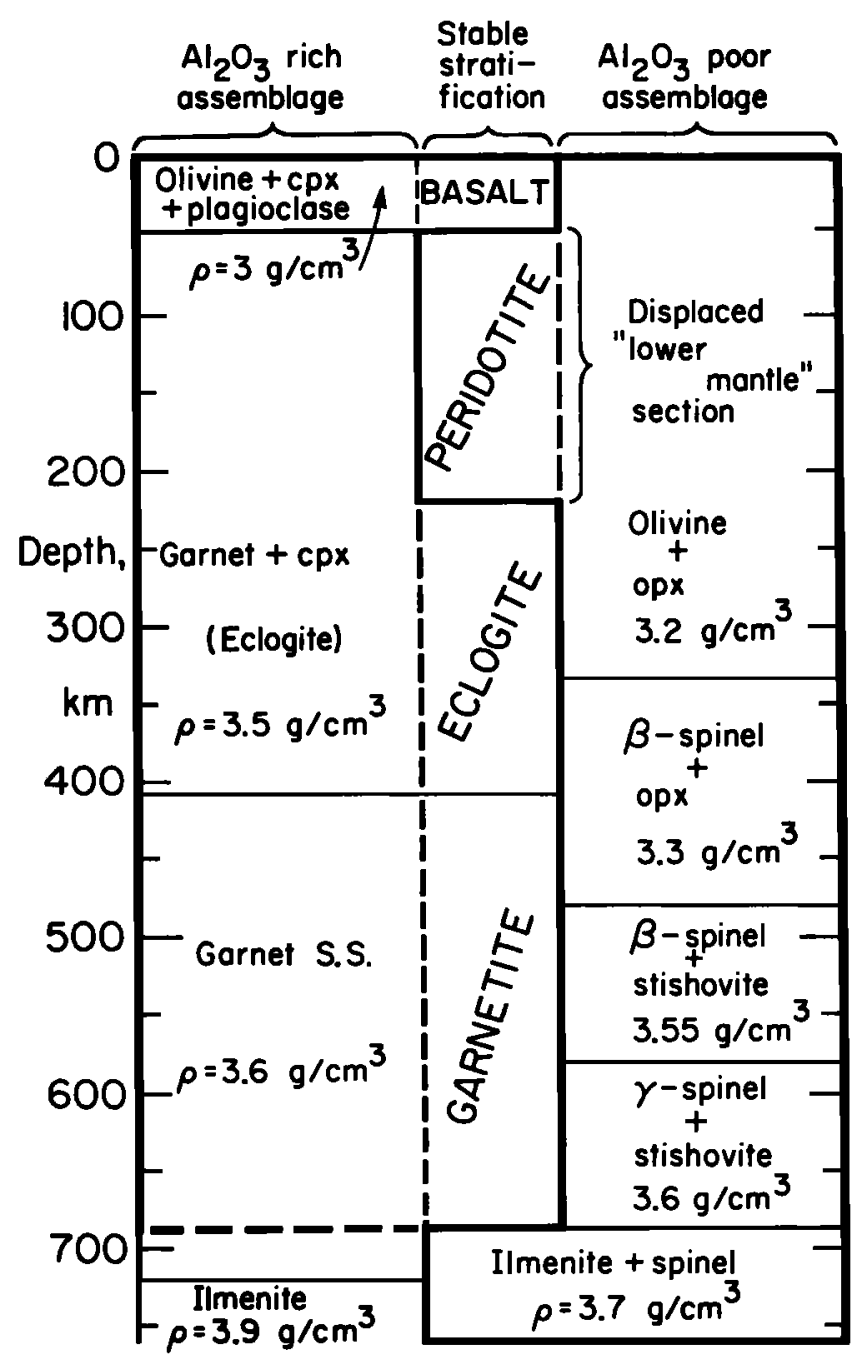

Figure 1. Zero pressure densities of basalteclogite (left) and peridotite (right) taken as a 1:1 $\mathrm{mix}$ of $\mathrm{MgSiO}_{3} \cdot \mathrm{Mg}_{2} \mathrm{SiO}_{4}$. The center colum gives the gravitationally stable configuration. The broad stability fleld of garnet prevents eclogite from sinking below about $670 \mathrm{~km}$.

velocity is much lower than olivine-rich assemblages but 18 well matched by eclogite. The $V_{P} / v_{S}$ ratio is about 1.77 , which is higher than olivine-rich assemblages. Garnet is the only major mineral that could increase this ratio. Some eclogites have properties similar to those required. These eclogites have densit les of about $3.48 \mathrm{~g} / \mathrm{cm}^{3}$ compared to $3.38 \mathrm{~g} / \mathrm{cm}^{3}$ for garnet pyrolite. Eclogite would, therefore, displace garnet peridotite, at least down to $400 \mathrm{~km}$. Figure 1 shows, In fact, that eclogite will sink to $670 \mathrm{~km}$. It appears that eclogite is not only consistent with the seismic data but is supertor when $v_{S}$ and $V_{P} / v_{S}$ are considered. From density considerations one can argue that eclogite, formed by subduction or by crystal fractionation, should settle into the transition region.

The velocity, density and $v_{p} / v_{S}$ change across the $400 \mathrm{~km}$ discontinuity [Hart et al., 1977] are much smaller than expected for the olivine-spinel transition [Llebermann, 1973, 1975]. Th1s would be the bottom of the cpx + ga to ga s.s. transition in the present model.

\section{Trace Elements}

We assume that the transition region has the composition of oceanic basalt [Engel et al., 1965] and have added this contribution to Gast's [1972] estimates of crustal abundances (Table 2). A recent estimate of whole earth abundances is also given. The crust and the eclogite layer account for nearly the total estimated incompatible trace element inventory of the earth. Incompatible trace elements in residual mantle ( $10 \%$ of basalt) ylelds a total mantle Inventory $50 \%$ greater than computed above. The use of basaltic abundances rather than the average abundances in oceanic crust, may overestimate the trace element content of the transition region.

The heat production of the crustal and eclogite layers corresponds to a heat flow of $1.2 \mu \mathrm{cal} / \mathrm{cm}^{2}$ sec of which about $70 \%$ comes from between 220 and $670 \mathrm{~km}$. The remainder of the mantle adds $0.5 \mu \mathrm{cal} /$ $\mathrm{cm}^{2}$ sec bringing the total heat flow in steady state to $1.7 \mu \mathrm{cal} / \mathrm{cm}^{2} \mathrm{sec}$.

Upper mantle convection in this system 1s composed of two superposed interacting layers. The lower layer (eclogite) is internally heated and therefore is characterized by narrow descending plumes [McKenzie et al., 1974]. The upper layer (peridotite) is driven primarily by heating from below and is characterized by narrow ascending plumes. Subduction zones will appear to be continuous since cold material delivered from the surface to $220 \mathrm{~km}$ will control the locations of the cold descending plumes in the underlying layer. The thick conduction layer associated with shields may also affect convection in the eclogite layer.

\section{Residual Mantle}

In the perched eclogite model the primitive upper and lower mantles are identical and represent the residuum after $\sim 20 \%$ partial melting. The present

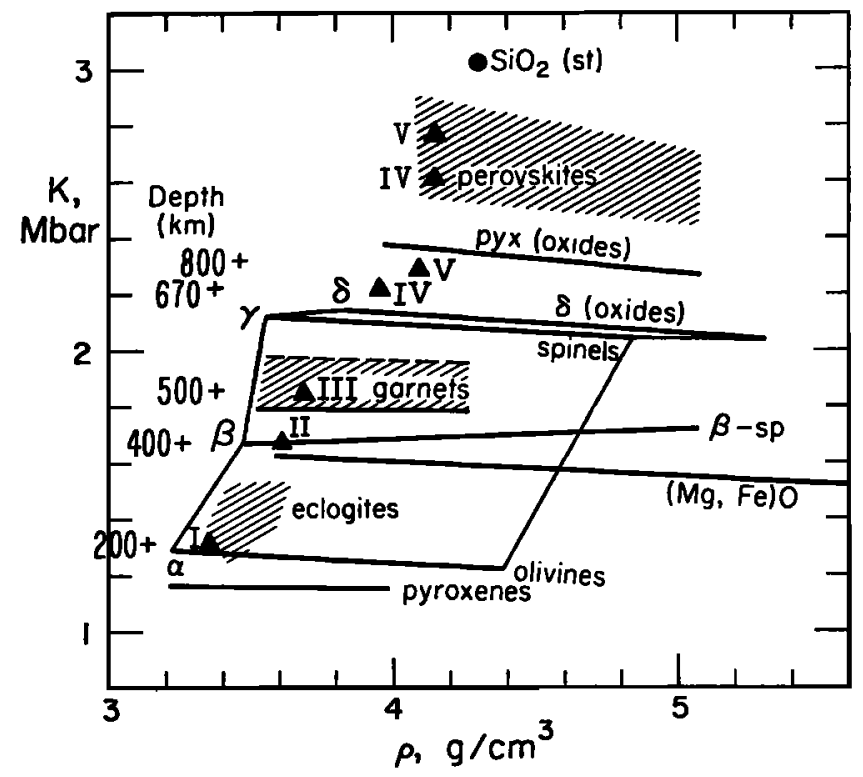

Figure 2. Bulk modulus vs. density for various minerals and various regions of the mantle [modified from Anderson, 1976, 1977]. Upper points for the lower mantle from Butler and Anderson [1978]. 
TABLE 1

Properties of Mantle Between 300 and $400 \mathrm{~km}$ Depth, Extrapolated to Surface Conditions

\begin{tabular}{|c|c|c|c|}
\hline$\nabla_{P}$ & $\mathbf{v}_{\mathbf{S}}$ & \multicolumn{2}{|l|}{$\mathrm{v}_{\mathrm{P}} / \mathrm{v}_{\mathrm{S}}$} \\
\hline \multicolumn{4}{|c|}{ MANTLE } \\
\hline $\begin{array}{l}8.29 \\
8.19 \\
8.36\end{array}$ & $\begin{array}{l}4.67 \\
4.69 \\
4.73\end{array}$ & $\begin{array}{l}1.77 \\
1.75 \\
1.77\end{array}$ & $\begin{array}{l}\text { Anderson and Hart [1976] } \\
\text { Helmberger and Engen [1974] } \\
\text { Hart et al [1977] }\end{array}$ \\
\hline \multicolumn{4}{|c|}{ MINERALS ( 1 ) } \\
\hline $\begin{array}{l}8.48 \\
7.84 \\
8.06 \\
9.16 \\
9.00\end{array}$ & $\begin{array}{l}4.93 \\
4.74 \\
4.77 \\
5.20 \\
5.00\end{array}$ & $\begin{array}{l}1.72 \\
1.65 \\
1.69 \\
1.76 \\
1.80\end{array}$ & $\begin{array}{l}\text { olivine } \\
\text { orthopyroxene } \\
\text { diopside } \\
\text { garnet } \\
\text { garnet }\end{array}$ \\
\hline \multicolumn{4}{|c|}{ MINERAL ASSEMBLAGES (1) } \\
\hline $\begin{array}{l}8.37 \\
8.30 \\
8.22 \\
8.31 \\
8.43\end{array}$ & $\begin{array}{l}4.87 \\
4.86 \\
4.63 \\
4.66 \\
4.69\end{array}$ & $\begin{array}{l}1.72 \\
1.71 \\
1.78 \\
1.78 \\
1.80\end{array}$ & $\begin{array}{l}\text { pyrolite } \\
\text { peridotite } \\
\text { eclogite }(23 \% \mathrm{ga}) \\
\text { eclogite }(37 \% \mathrm{ga}) \\
\text { eclogite }(51 \% \mathrm{ga})\end{array}$ \\
\hline
\end{tabular}

(1) Green and Liebermann [1976]

Simmons and Wang [1971]

Manghnant et al [1974], Anderson [1977]

upper mantle may have been further processed and be 811 ghtly more depleted in $\mathrm{SIO}_{2}, \mathrm{Al}_{2} \mathrm{O}_{3}, \mathrm{CaO}$, etc. than the present lower mantle. To calculate the composition of residual mantle, we subtract the eclogite layer from primitive mantle [Ganapathy and Anders, 1974]. The residual mantle, which we assume occurs abnve $220 \mathrm{~km}$ and below $670 \mathrm{~km}$, is remarkably almilar to other estimates of upper mantle composition (Table 3).

\section{Discussion}

If the earth began to differentiate while it was still a small body the surface layer would be

TABLE 2

Abundances of Some Trace Elements in Crust Plus Transition Region $(220-670 \mathrm{~km})$ and in the

Whole Mantle (Expressed in ppm in Whole Mantle)

Element

(1)

$\begin{array}{lcc}\mathrm{Ba} & 2.5 & 8.5 \\ \mathrm{U} & 0.04 & 0.03 \\ \mathrm{Sr} & 28.2 & 90 \\ \mathrm{Rb} & 0.55 & 0.97 \\ \mathrm{~K} & 305 & 283\end{array}$

(1) Crust (Model C, Gast, 1972) plus transition region (taken as oceanic tholeite, Engle et al, 1965)

(2) Mantle [Ganapathy and Anders, 1974]
TABLE 3

Upper Mantle Composition

\begin{tabular}{lrrr}
\hline & $(1)$ & $(2)$ & $(3)$ \\
$\mathrm{SiO}_{2}$ & 46.8 & 44.5 & 46.1 \\
$\mathrm{Al}_{2} \mathrm{O}_{3}$ & 2.3 & 2.6 & 4.3 \\
$\mathrm{FeO}_{\mathrm{MgO}}$ & 7.8 & 8.6 & 8.2 \\
$\mathrm{CaO}$ & 40.9 & 41.7 & 37.6 \\
& 2.0 & 2.3 & 3.1 \\
\hline
\end{tabular}

(1) This study. Residual mantle after removal of eclogite layer $(220-670 \mathrm{~km})$ taken to have composition of oceanic tholeilte [Kay et al., 1970] from primitive mantle of Ganapathy and Anders [1974].

(2) Upper mantle [White, 1967].

(3) Pyrolite [Ringwood, 1975].

basaltic. As the upper mantle cools it enters the eclogite stability field and the surface layer becomes gravitationally unstable. This material is denser than "normal" mantle, residual upper mantle or primitive depleted lower mantle at moderate pressure. It therefore sinks into the lower mantle to a depth controlled by phase changes in eclogite and the lower mantle. Ilmenite and perovskite phase changes occur at lower pressure in $\mathrm{Al}_{2} \mathrm{O}_{3}$-poor material than in eclogite or primitive upper mantle. Eclogite can therefore sink to $670 \mathrm{~km}$ but no further. This becomes the boundary between the upper and lower mantle. Eclogite displaces primitive lower mantle upwards. The displaced portion of the lower mantle rides on top of the eclogite layer, which is presently at $\sim 220 \mathrm{~km}$, and provides a source region quite distinct from the underlying eclogite.

Convection in the eclogite layer results in thermal boundary layers on both sides of the chemical discontinuity at $220 \mathrm{~km}$. This high thermal gradient may be the cause of "kinked geotherms" found in some kimberlite inclustons [Boyd, 1973].

Acknowledgments. I would like to acknowledge discussions with Leon Silver and Frank Richter. Anton Hales reviewed the manuscript. This research was supported by NASA NGL05-002-069. Contribution No. 3239, Div. Geol. and Planet. Sci., Caltech, Pasadena, CA 91125.

\section{References}

Akaogi, M., and S. Akimoto, Pyroxene-garnet solid solution equilibria in the systems $\mathrm{Mg}_{4} \mathrm{Si}_{4} \mathrm{O}_{12}$ $\mathrm{Mg}_{3} \mathrm{Al}_{2} \mathrm{Si}_{3} \mathrm{O}_{12}$ at high pressures and temperatures, Phys. Earth Planet. Int., 15, 90-106, 1977.

Anderson, D. L., and R. S. Hart, An Earth model based on free oscillations and body waves, $\mathrm{J}$. Geophys. Res., 81, 1461-1475, 1976.

Anderson, D. L., Composition of the mantle and core, in Annual. Review of Earth and Planetary Sciences, F. A. Donath (ed.), Annual Revlews, Inc., 179-202, 1977.

Anderson, D. L., Latest information from seismlc 
observations In the Earth's mantle, T. F. Gaskell (ed.), Academic Press, N.Y., 1967.

Anderson, D. L., The deep structure of continents, J. Geophys. Res., 1979.

Boyd, F. R., A pyroxene geotherm, Geochim. Cosmochim. Acta, 37, 2533-2546, 1973.

Burdick, L. J. and $\bar{D}$. L. Anderson, Interpretation of velocity profiles of the mantle, J. Geophys. Res., 1070-1074, 1975.

Burdick, L. J. and D. V. Helmberger, The upper mantle $P$ velocity structure of the western United States, J. Geophys. Res., 83, 1699-1712, 1979.

Butler, R. and D. L. Anderson, Equation of state fits to the lower mantle and outer core, Phys. Earth Planet. Int., 17, 147-162, 1978.

Carter, J. J., Mineralogy and chemistry of the Earth's upper mantle based on the partial fusionpartial crystallization model, Geol. Soc. Am. Bu11., 81, 2021-2034, 1970.

Engel, A. E. J., C. G. Engel and R. G. Havens, Chemical characteristics of oceanic basalts and the upper mantle, Geol. Soc. Am. Bull., 76, 719$734,1965$.

Gaffney, E. S. and D. L. Anderson, Effect of lowspin $\mathrm{Fe}^{2+}$ on the composition of the lower mantle, J. Geophys. Res., 78, 7005-7014, 1973.

Ganapathy, R. and E. Anders, Bulk compositions of the moon and earth estimated from meteorites, Proc. Lunar Sc1. Conf. 5th, 1181-1206, 1974.

Gast, P. W., The chemical composition of the earth, the moon and meteorites, in The Nature of the Solid Earth, p. 19-40, E. C. Robertson (ed.), McGrawHill, Inc., N.Y., 1972.

Green, D, and R. C. Liebermann, Phase equilibria and elastic properties of a phyrolite model for the oceanic upper mantle, Tectonophysics, 32, 61-92, 1976.

Hales, A. L., K. Muirhead and J. Kynn, Upper-mantle travel times in Australia, Phys. Earth Planet. Int. $11,109-118,1976$.

Helmberger, D. V. and G. Engen, Upper mantle shear structure, J. Geophys. Res., 79, 4017-4028, 1974.

Ito, K., and G. C. Kennedy, The composition of liquids formed by partial melting of eclogites at high temperatures and pressures, J. Geol., 82, 383-392, 1974.

Ito, E. and Y. Matsui, Silicate IImentes and the post-spinel transformations, in High-Pressure Research, M. Manghnan 1 and S. Akimoto (eds.), Academic Press, 193-208, 1977.

Kay, R., N. Hubbard and P. W. Gast, Chemical characteristics and origins of oceanic ridge volcanic rocks, J. Geophys. Res., 75, 1585-1613, 1970.

King, D. W, and $G$. Calcagnile, $p$ wave velocities in the upper mantle beneath Fennoscandia and western Russia, R. Astron. Soc., Geophys. J., 46, 407-432, 1976.

Lehmann, I., S and the structure of the upper mantle, Geophys. J. R, astr. Soc., 4, 124-138, 1961.

Liebermann, R. C., Elasticity of the olivine-spinel and olivine- $\beta$ phase transformation and the 400kilometer discontinuity of the mantle, J.Geophys. Res., 78, 7015-7019, 1973.

Liebermann, R. C., Elasticity of olivine ( $\alpha$ ), beta $(B)$, and spinel $(\gamma)$ polymorphs of germanttes and silicates, R. Astron. Soc., Geophys. J. 42, 899-930, 1975 .

Liu, L. G., The system enstatite-pyrope at high pressures and temperatures and the mineralogy of the Earth's mantle, Earth Planet. Sci. Lett., $36,237-243,1977$.

Manghnan1, M., R. Ramananantoandro, and S. Clark, Compressional and shear wave velocities in granulite facies rocks and eclogites to $10 \mathrm{kbar}$, J. Geophys. Res., 79, 5424-5446, 1974.

Mason, B., Composition of the Earth, Nature, 211, $616-618,1966$.

McKenzle, D. P., J. Roberts and N. Weiss, Convection in the Earth's mantle: toward a numerical simulation, J. Fluid Mech., 62, 465$538,1974$.

Ringwood, A. E., Composition and Petrology of the Earth's Mantle, McGraw-H111, N.Y., 1975, 618 pp.

Simmons, G., and 11 . Wang, Single crystal elastic constants and calculated aggregate properties: a handbook, the Mass. Inst. Technol. Press, Cambridge, Mass., 370 pp., 1971.

White, I. G., U1trabasic rocks and the composition of the upper mantle, Earth Planet. Sc1. Lett., 3, 11-18, 1967.

(Recelved April 19, 1979; accepted Apri1 30, 1979.) 